\title{
The influence of the slowing of Earth's rotation: a hypothesis to explain cell division synchrony under different day duration in earlier and later evolved unicellular algae
}

\author{
E. Costas, S. González-Gil, V. López-Rodas \& A. Aguilera \\ Genética, Producción Animal, Facultad de Veterinaria, Universidad Complutense; \\ E-28040 Madrid, Spain
}

\begin{abstract}
Every year the Earth's rotation period is reduced, mainly due to the tidal drag of the moon. The length of day increases continuously by about $1 \mathrm{~h}$ every 200 million years. The period of rotation around the Sun remains constant; hence, the length of the year remains constant, so years acquire progressively fewer days. Many unicellular algae show rhythmicity in their cell division cycle. If primitive algae evolved under a shorter day duration, then it is possible that the earlyevolved algae had to synchronize their cell division cycle to shorter lengths of day than did laterevolved algae. We tested this hypothesis by growing Cyanobacteria, Dinophyceae, Prasinophyceae, Bacillariophyceae and Conjugatophyceae (evolutionary appearance probably in this order) at $8: 8 \mathrm{~h}$ light-dark cycles (LD), 10:10 LD, and 12:12 LD, at 20 or $27^{\circ} \mathrm{C}$. Cyanobacteria synchronized their cell division cycles optimally at 8:8 h LD, Dinophyceae and Prasinophyceae at 10:10 h LD, and Conjugatophyceae and Bacillariophyceae at $12: 12 \mathrm{~h} \mathrm{LD}$. The synchrony of cell division was scarcely affected by temperature. Results suggested that the early evolved unicellular autotrophic organisms such as the Cyanobacteria synchronized their cell division cycle under a shorter day duration than later-evolved unicellular algae, and these traits may have been conserved by quiescent genes up to the present day.
\end{abstract}

\section{INTRODUCTION}

Biological adaptation processes depend strongly on geological history, and this may apply to adaptation to the length of day. It is a well-known hypothesis among geologists that the lengthening of day occurred in the geological past because the Earth's initially rapid rotation slowed down. This is mainly caused by the tidal drag of the moon, which moves farther from Earth by about $6 \mathrm{~cm}$ per year and gains the rotational energy lost by Earth, since the total rotational energy of the Earth-moon system is conserved (Bott, 1982; Foster, 1991). The increase in the length of day is estimated at between 8 to 27 sec per 1 million years (Muller \& Stephenson, 1975; Bott, 1982; Foster, 1991). Using a mean rate of $18 \mathrm{sec}$ per 1 million years, the length of day increased by about $1 \mathrm{~h}$ every 200 million years. The day would thus have lasted around $21 \mathrm{~h}$ at the beginning of the Paleozoic, 560 million years ago. As days became longer, the years acquired progressively fewer days, since the year, defined as the period of Earth's trip around the sun, did not change because the distance between the sun and the Earth remained constant (Bott, 1982; 
Foster, 1991). The Middle Devonian year, 375 million years ago, had probably a maximum of 407 days, as Wells (1963) calculated from daily and annual banding patterns in fossil rugose corals. This fossil "clock" value corresponds to an increase in the length of day at a rate of $24 \mathrm{sec}$ per 1 million years and is in agreement with the estimated slowing of the Earth's rotation.

There are other biological phenomena indicating that the length of day increased throughout geological times. Examples are the ability of the endogenous circadian clock to synchronize its period optimally to a certain length of day (Bünning, 1973; Sweeney, 1987) and the day-night synchronization of the cell division cycle, which may or may not be coupled to the circadian clock (Edmunds, 1988). Earlier evolved organisms possibly had to synchronize their circadian clocks and cell cycles to shorter days than laterevolved organisms.

Many species of unicellular algae exhibit rhythmic cell division and divide synchronously once every $24 \mathrm{~h}$, if they are grown in a light-dark cycle with a period of $24 \mathrm{~h}$. Rhythmic cell division has been observed in laboratory cultures and in the field, e.g. in dinoflagellates, diatoms, Coccolithophores, Haptophytes, Prasinophytes, Conjugatophytes and Euglenophytes (Sweeney \& Hastings, 1958; Edmunds \& Funch, 1969; Chisholm \& Brand, 1981; Brand, 1982; Alvarez et al., 1988; Costas \& López-Rodas, 1991a, 1991b; reviews by Edmunds, 1984, 1988). In several of these species, cell division is clearly coupled to the circadian clock, with persisting rhythmicity in constant conditions, and some observations on temperature stability of the free-running period, and on phase shifts by light pulses. This has partly been demonstrated, e.g. in dinoflagellates (Sweeney \& Hastings, 1958; Homma \& Hastings, 1989a, 1989b) and Euglenophytes (Edmunds et al., 1976, 1982), but not in diatoms (Ostgaard \& Jensen 1982; Chisholm \& Brand, 1981). The phase of the circadian clock is accurately transferred from the mother to the daughter cells in dinoflagellates (Homma et al., 1990). The molecular basis of cell division synchrony remains obscure, but several molecular mechanisms have been proposed to explain the control of the cell division cycle of microalgae (Edmunds, 1988; Costas \& López-Rodas, 1991a).

Cell division synchrony is generally interpreted as an adaptation to daily changes in the environment (Edmunds, 1988). Cell division in cultures of unicellular algae was synchronized by light-dark cycles with a total length of $24 \mathrm{~h}$ (Edmunds, 1965, 1984, 1988; Costas \& López-Rodas, 1990, 1991b). The ancient Cyanobacteria (Oxyphotobacteria) and intermediate groups, such as the Prasinophyceae, date back to Precambrian times and may have experienced a primitive Earth with a day duration less than $24 \mathrm{~h}$.

If ancient organisms had to synchronize their circadian clocks and cell division cycles to a day duration shorter than $24 \mathrm{~h}$, the question arises whether the representatives of ancient groups would have conserved this trait and would still exhibit better cell division synchrony with a shorter day duration. To test this question and to investigate the grade of cell division synchrony in a few early-evolved and later-evolved algal species at day durations differing from $24 \mathrm{~h}$ and at the traditionally used day duration of $24 \mathrm{~h}$ was the objective of this paper. Since temperature may change cell cycle length and the period of circadian rhythms (Sweeney, 1987; Balzer \& Hardeland, 1988), the experiments were performed at two different temperatures. 


\section{MATERIALS AND METHODS}

Clonal cultures from the following 6 phylogenetically distant organisms were used from the algal culture collection of the Universidad Complutense de Madrid: Nostoc sp. clone NV 02 and Chroococcus clone Ch 01 (Cyanobacteria), Prorocentrum triestinum Schiller clone Pt 3V (Dinophyceae), Tetraselmis clone Te 40 (Prasinophyceae), Spirogyra insignis Hassall clone Si UMB (Conjugatophyceae), and Phaeodactylum tricornutum Bohlin clone $\mathrm{Ph} 01$ (Bacillariophyceae).

Three replicates of each clone were cultivated under photocycles of $8: 8 \mathrm{~h} \mathrm{LD}$, $10: 10 \mathrm{~h} \mathrm{LD}$ and $12: 12 \mathrm{~h} \mathrm{LD}(\mathrm{L}=$ light phase, $\mathrm{D}=$ dark phase $)$ at a photon fluence rate of $100 \mu \mathrm{mol} \mathrm{m} \mathrm{m}^{-2} \mathrm{~s}^{-1}$. All replicates were grown in axenic culture in $\mathrm{f} / 2$ medium (Guillard, 1975 ) at $20 \pm 1{ }^{\circ} \mathrm{C}$ and in parallel at $27 \pm 1{ }^{\circ} \mathrm{C}$. Once every week, exponentially growing cultures were maintained by transferring an inoculum of $1000 \pm 15$ cells of each culture to $20 \mathrm{ml}$ fresh medium.

Prior to counting cell numbers, the cultures were pre-adapted for 20 days in each of the environmental conditions. Cell numbers were counted at 2-h intervals through each light-dark cycle. The degree of synchronized cell division was defined as the percentage of those cells performing cytokinesis simultaneously during a certain 2-h interval, with respect to all cells that divided during the respective light-dark cycle. A 2-h interval was chosen because cytokinesis lasts 60-90 min in the species analysed (further details in Costas \& López-Rodas, 1990, 1991a, b, c; Aguilera, 1991).

Cell number was determined in Cyanobacteria by counting samples in a hemocytometer, which was appropriate since both Nostoc and Chroococcus grew in cultures as isolated cells. Prorocentrum triestinum, Tetraselmis and Phaeodactylum were counted in settling chambers. In Spirogyra, all cells of a filament were counted using an inverted microscope. Except for Spirogyra, the minimal sample size was determined by the progressive mean technique with a confidence limit of $5 \%$ (Williams, 1977). A direct video micrograph recording, using a Zeiss Axiovert-Sony video system, was used to detail observations on cell cytokinesis in different cultures and to facilitate cell counts in Spirogyra.

Each experiment on a particular light-dark cycle was performed three times, and three samples were investigated at 2 - $h$ intervals. Statistical analysis was possible with a sample size of 9 for each light-dark cycle.

\section{RESULTS}

Nostoc sp. and Chroococcus sp., the two cyanobacterial and most ancient species, exhibited maximum cell division toward the end of the night (Figs 1,2). Highest cell division synchrony occurred at 8:8 LD in Nostoc sp. (Fig. 1) and at 8:8 LD and 10:10 LD in Chroococcus sp. (Fig. 2). The statistical significance of the occurrence of maxima at the short periods of 16 or $20 \mathrm{~h}$ and the occurrence of minimum synchronization at the period of $24 \mathrm{~h}$ in $12: 12 \mathrm{LD}$ were ascertained by a posteriori Student-Newman-Keuls test (SNK test; $\mathrm{p}<0.01$ ). These effects were independent of temperature (Figs 1, 2).

In contrast, the species of the most recently evolved groups, Spirogyra insignis (Conjugatophyceae; Fig. 3), as well as Phaeodactylum tricornutum (Bacillariophyceae; Fig. 4), exhibited significant synchronization of cell division only at a period of 24 h, i.e. 

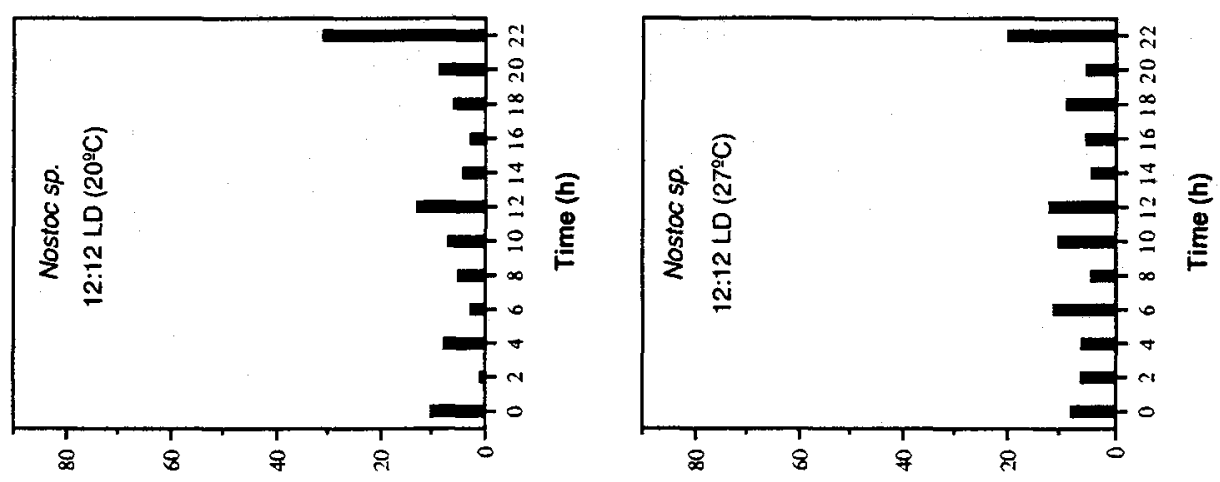

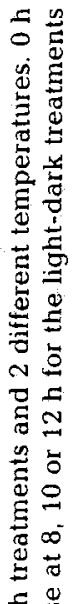

壳总

क्ष
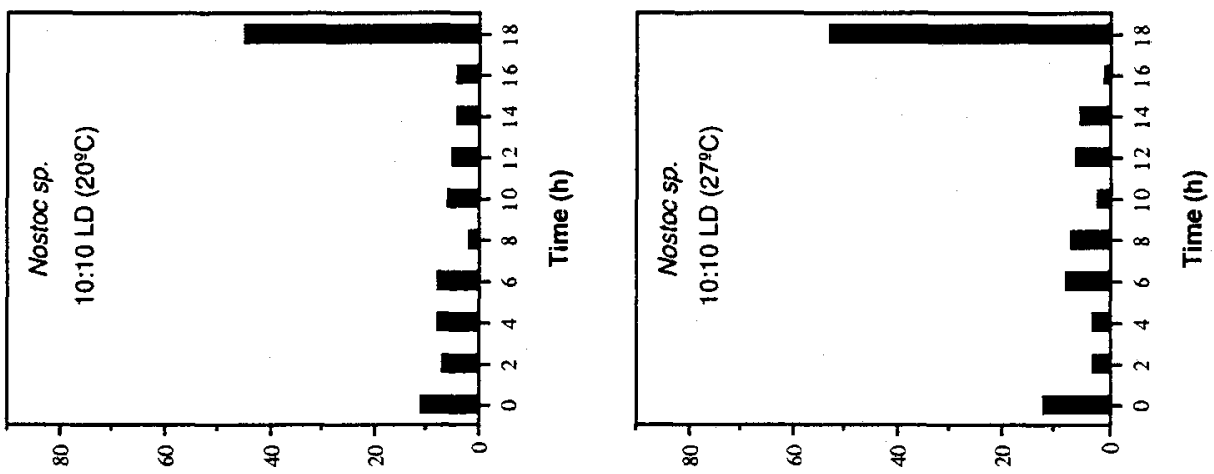

형 흥

范

焉

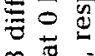

in 9

范

可

$=\frac{\pi}{3}$

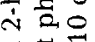

응

正舟

马ि

过

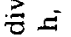

g

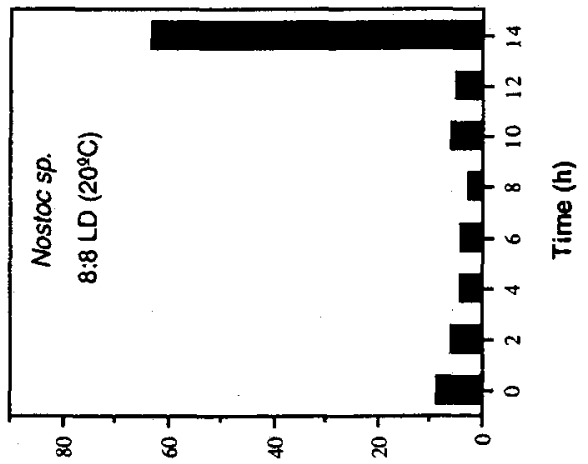

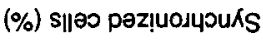

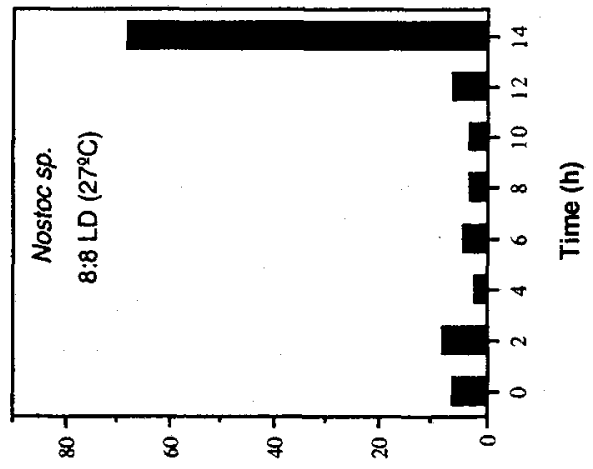

(\%) s||əo pez!uosuouks

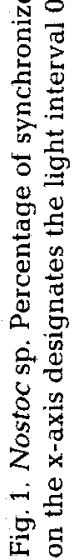



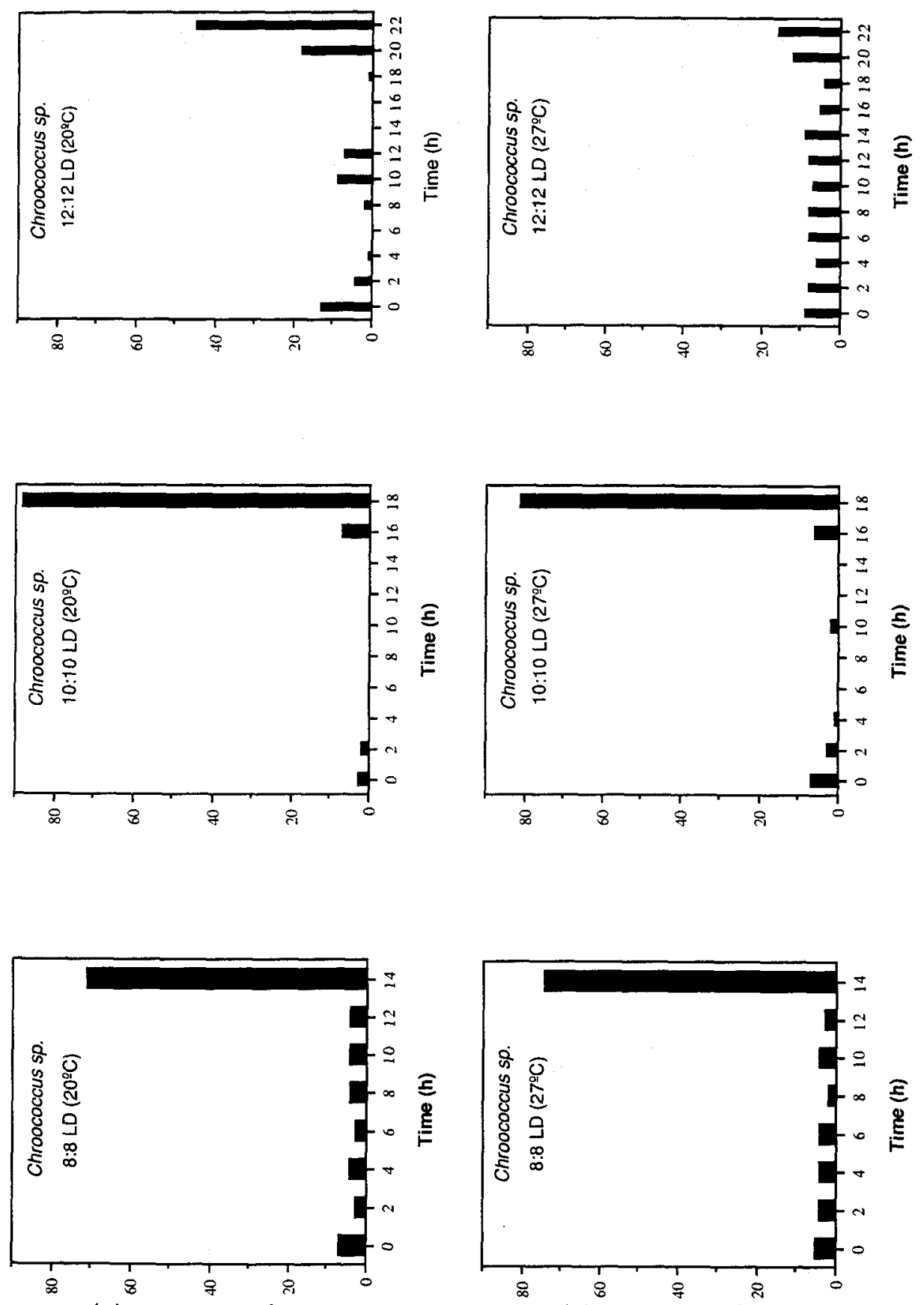

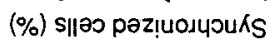

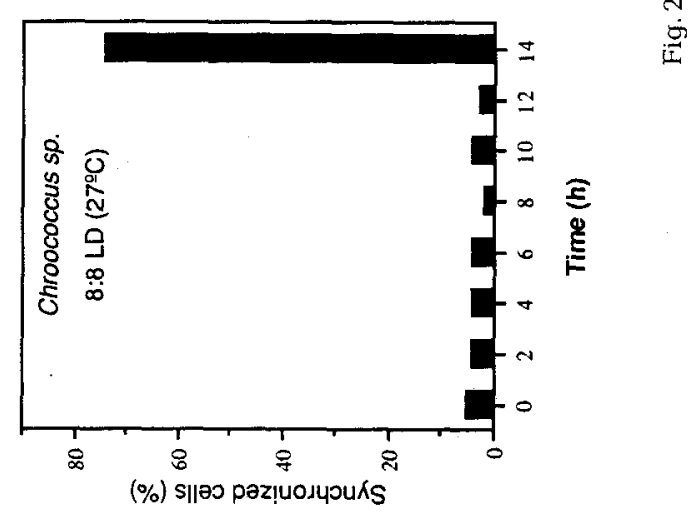



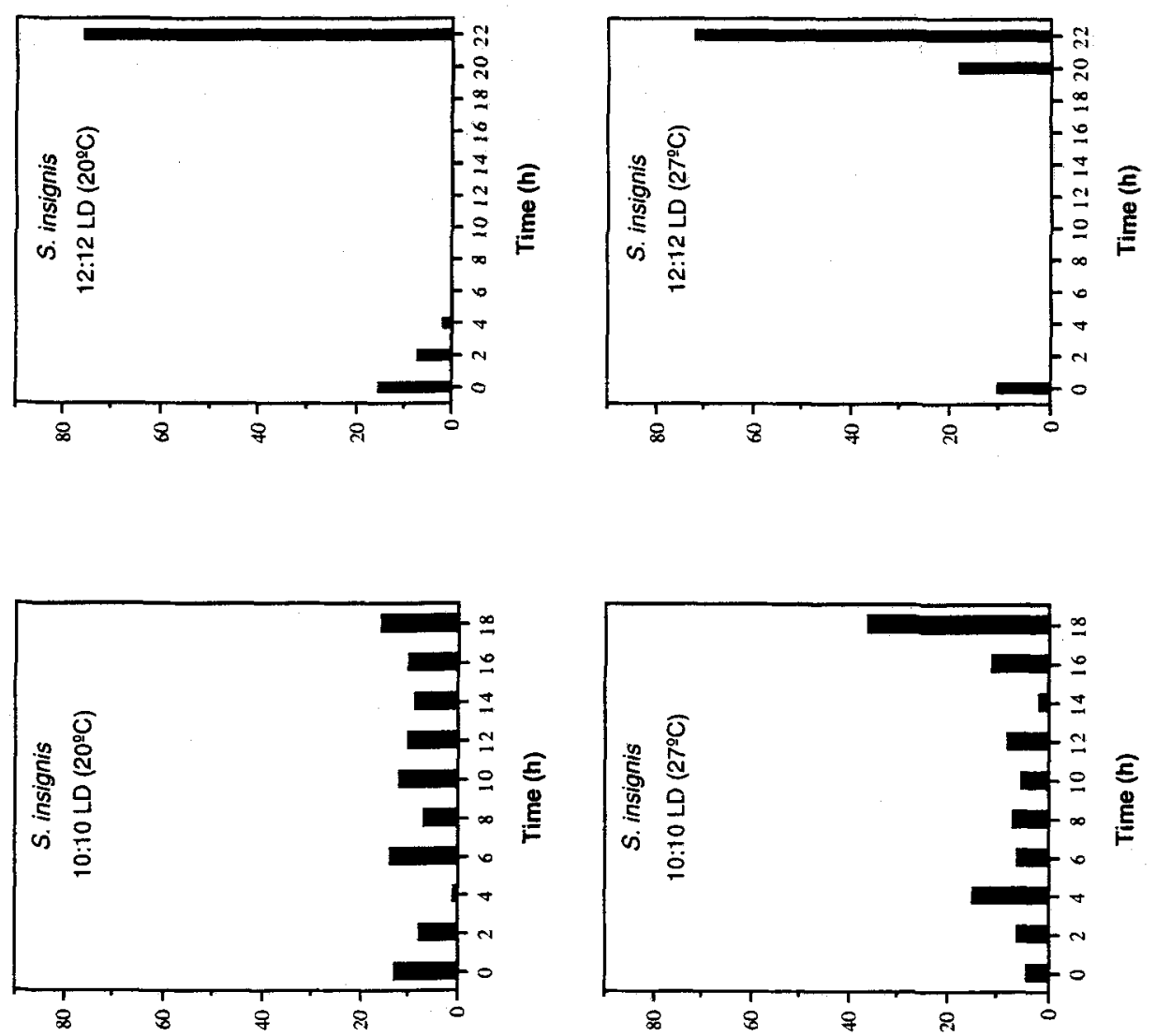

告)

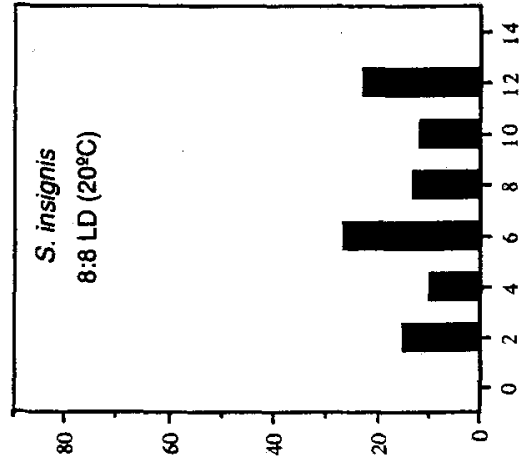

(\%) sњəo pezịudyouks

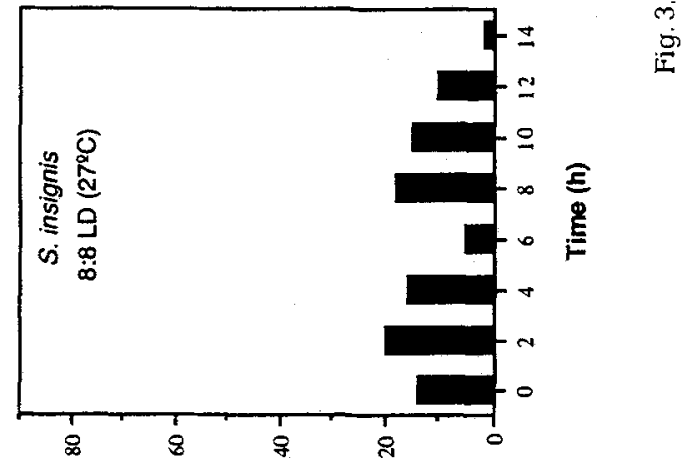

(\%) S॥əo pəz!UоנцоикS 

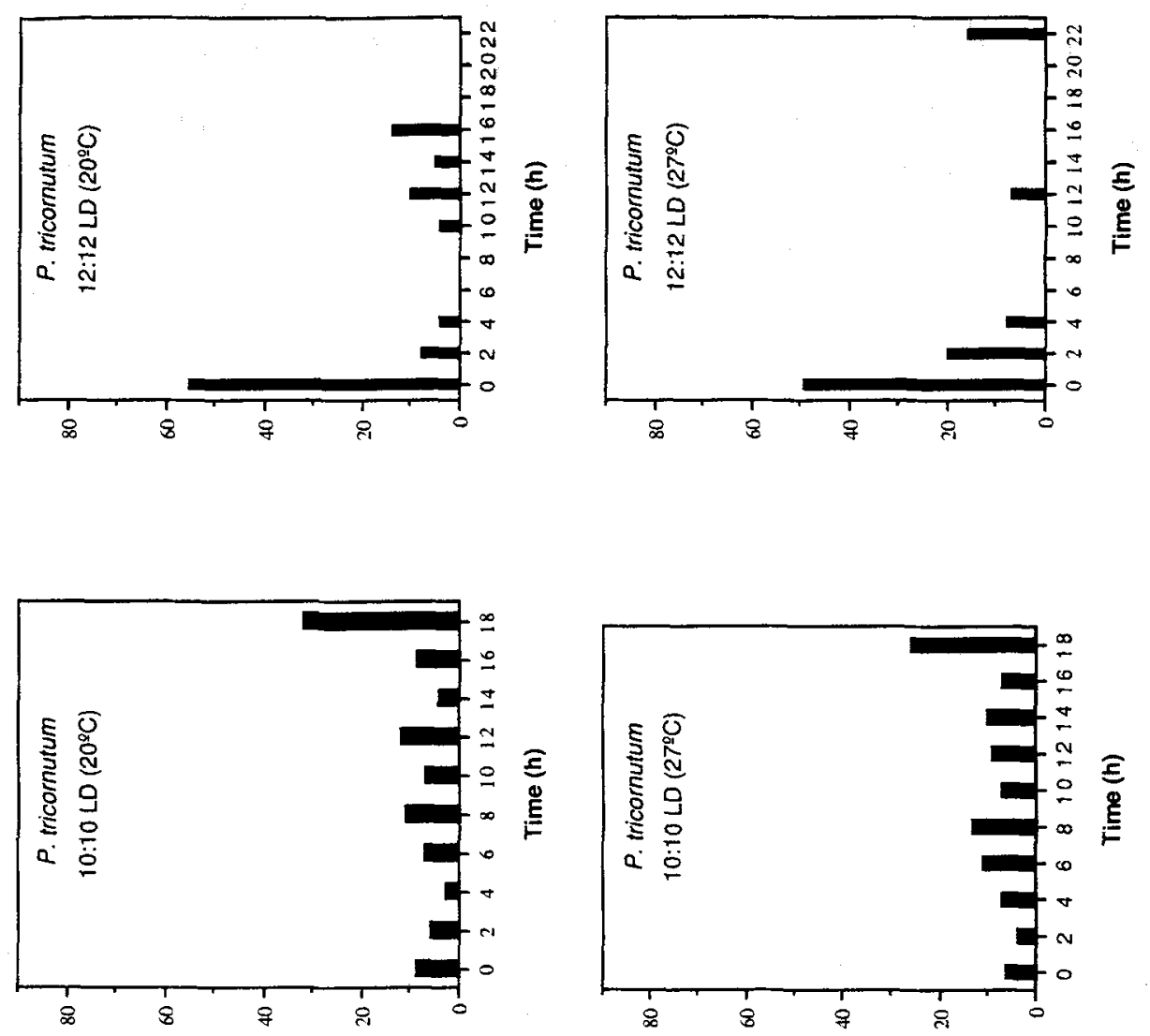

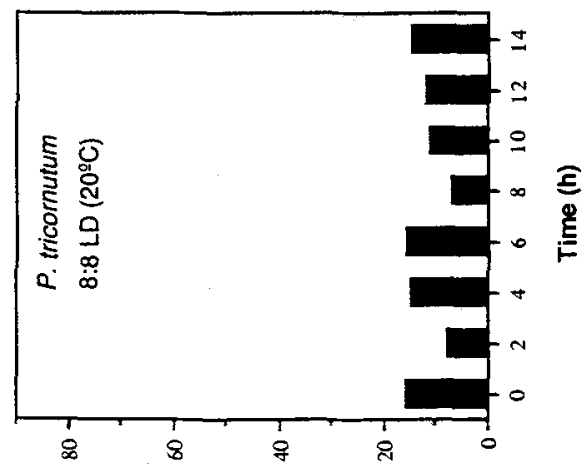

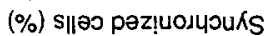

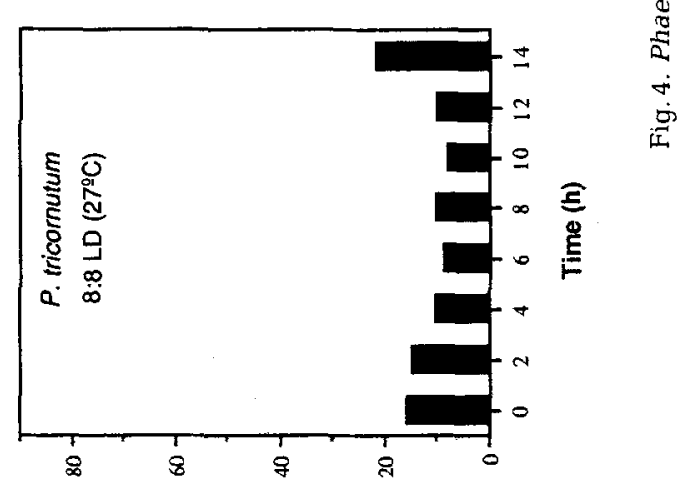

(\%) S॥əo paz!uodyouks 

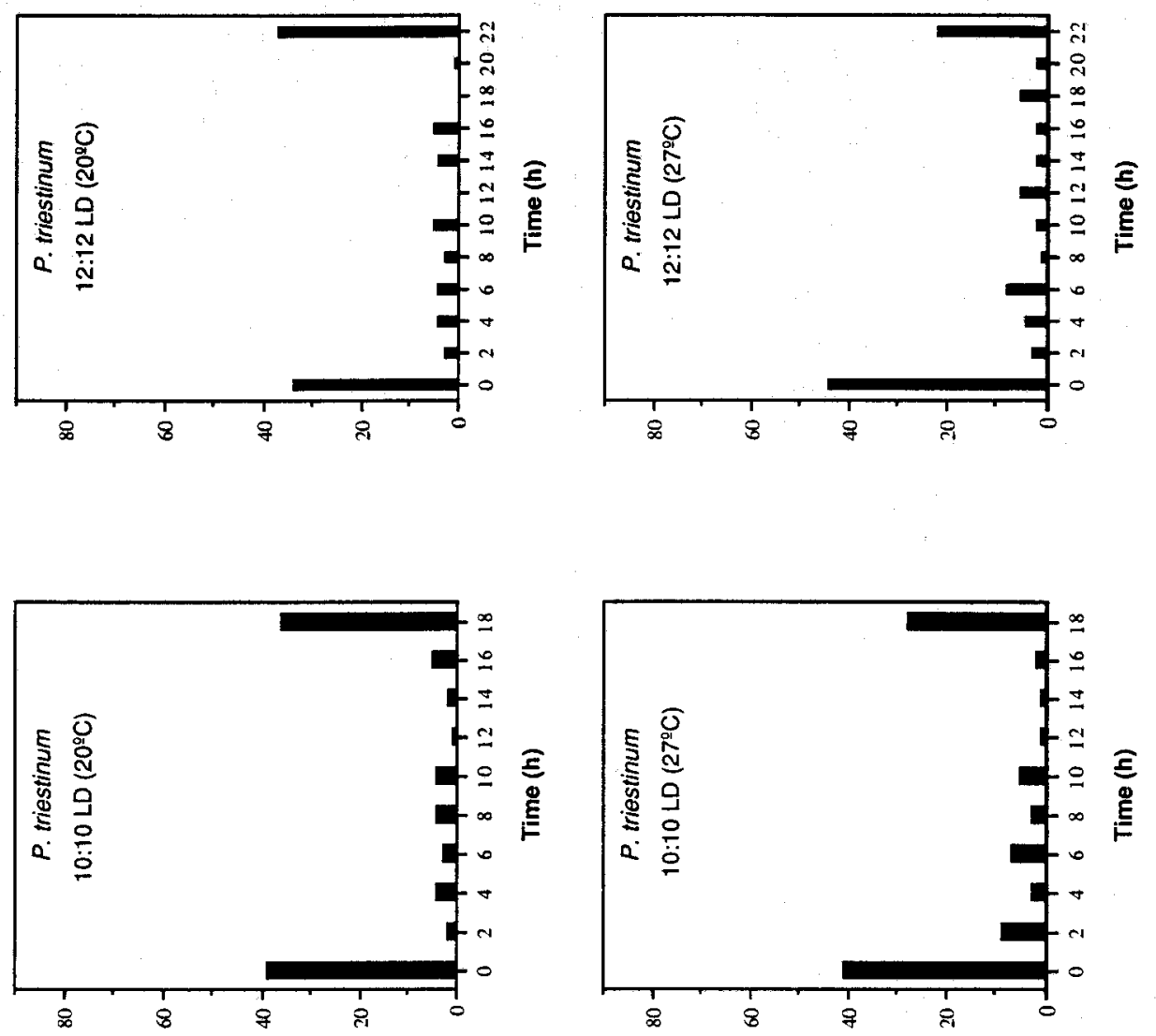

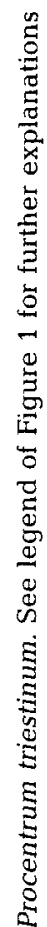

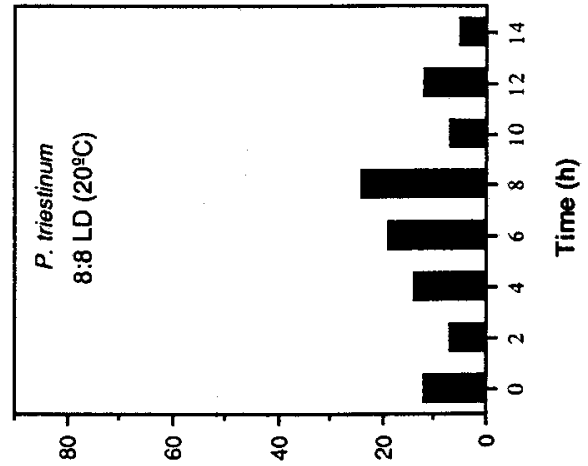

(\%) S\|әอ paz!̣ouyouks

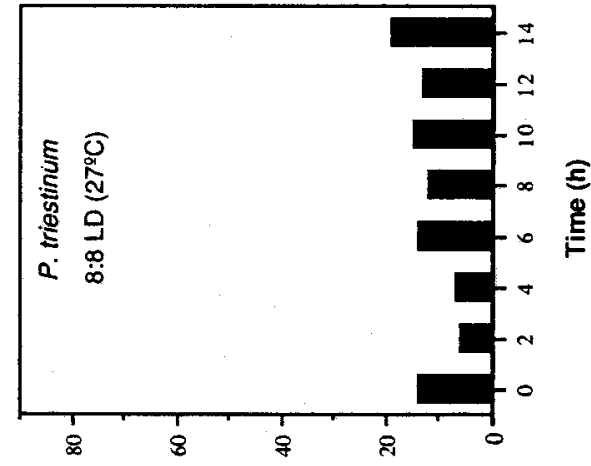

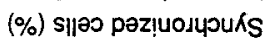



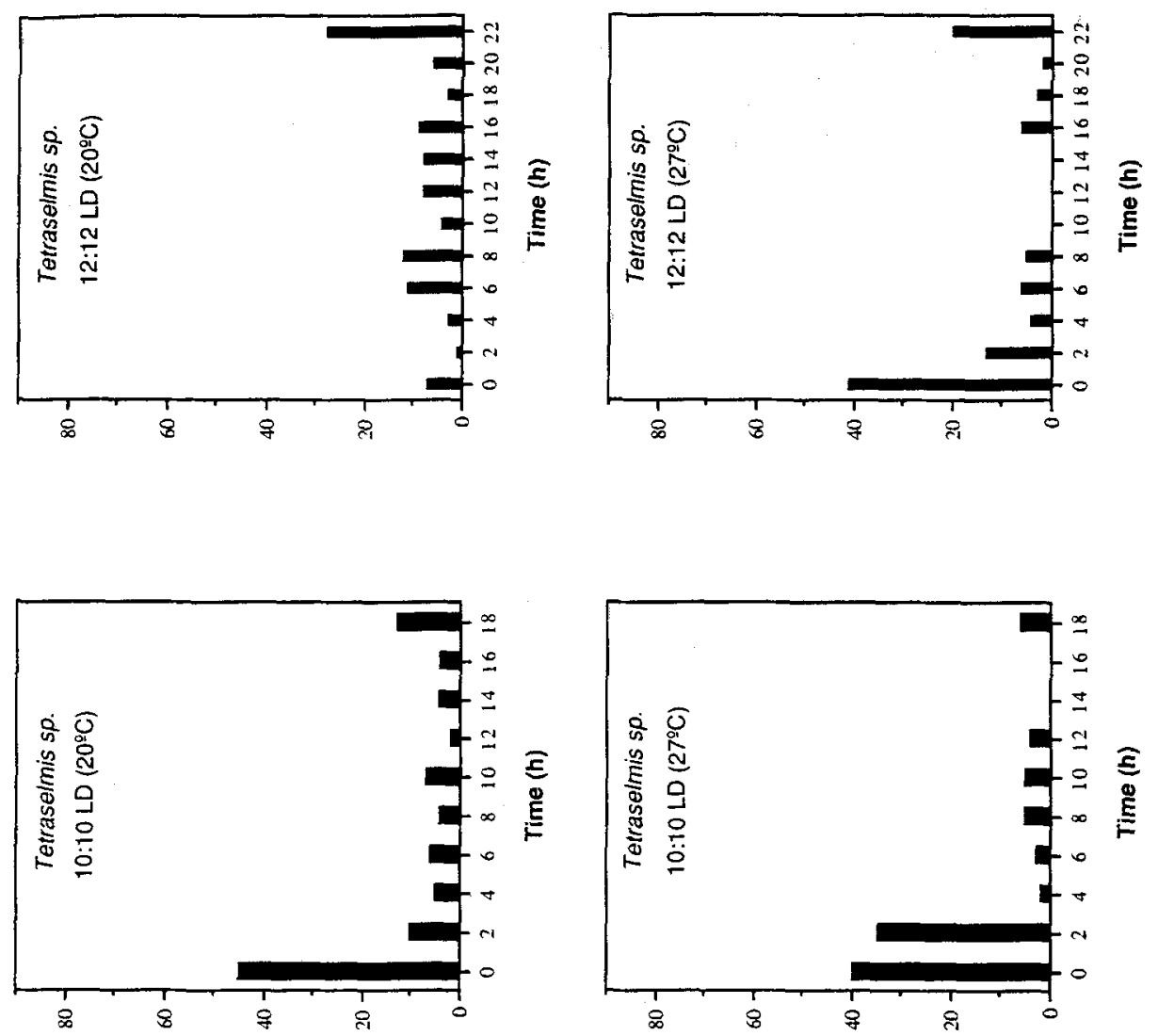

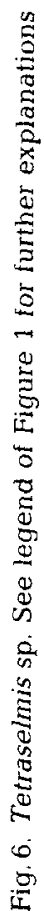

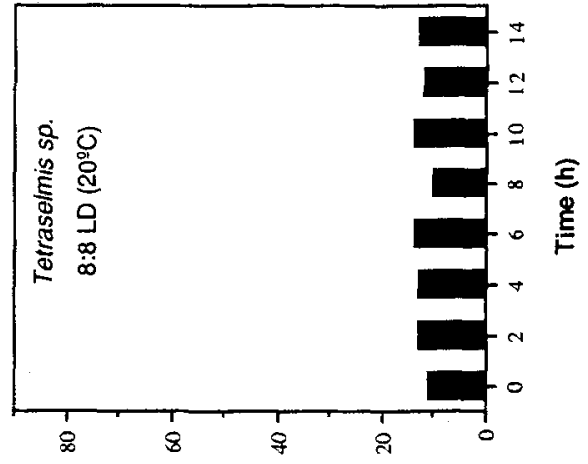

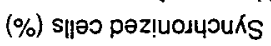

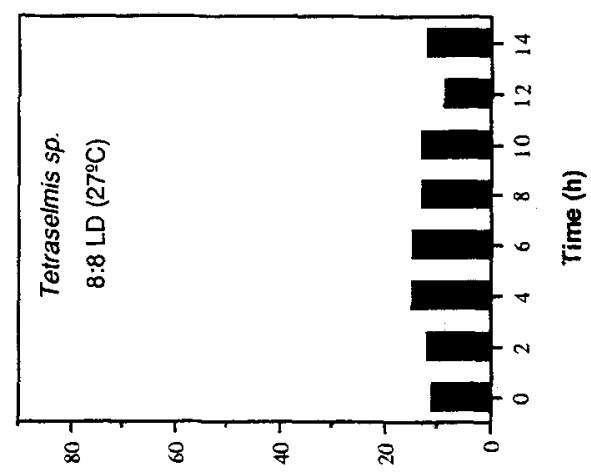

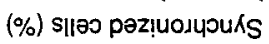


under 12:12 h LD cycles (SNK test; significant at $\mathrm{p}<0.01$ ). Maximum cell division occurred again towards the end of the night in both species (Figs 3,4), and at the beginning of the day in P. tricornutum at 10:10 LD (Fig. 4).

The species of the intermediately evolved groups, i.e. Prorocentrum triestinum (Dinophyceae; Fig. 5) and Tetraselmis sp. (Prasinophyceae; Fig. 6), exhibited synchronization at cycle periods of 24 and $20 \mathrm{~h}$, with maximum cell division at the end of the night and the beginning of the day, but not at the period of $16 \mathrm{~h}$.

In the investigated samples, the described differences in cell division synchrony among the different day lengths were found to be significant at $p<0.01$, as indicated by single classification analysis of variance (ANOVA; Sokal \& Rohlf, 1981); while temperature did not significantly change the day-length patterns (Figs 1-6).

\section{DISCUSSION}

The earlier-evolved algae synchronized their cell division cycles to a shorter length of day than the later-evolved algae, which evolved when the duration of a day had increased. Geological records and molecular phylogenies suggest that: (1) Cyanobacteria probably appeared on Earth about 2500 million years ago; (2) Dinophyceae and ancient Prasinophyceae, about 1500 million years ago; and (3) the filamentous Conjugatophyceae and pennate Bacillariophyceae, about 500000 years ago (Margulis \& Schwartz, 1982; Dodge, 1983; Herzog et al., 1984; Gunderson et al., 1987; Baroin et al., 1988; Lee, 1989; Lenaers et al., 1989; Knoll, 1992; van den Hoek, 1993). Assuming an average increase in a day's duration of $1 \mathrm{~h}$ every 200 million years (see "Introduction"), a day may have lasted 11.5, 16.5, or $21.5 \mathrm{~h}$ at the first appearance of groups (1), (2), or (3). In the present investigation, only a few species of each group were analysed. The $8: 8 \mathrm{~h}$, $10: 10 \mathrm{~h}$ and $12: 12 \mathrm{~h}$ LD day lengths used represent only a tentative approach; but the results support the hypothesis that the earlier-evolved algae were able to synchronize their cell division to shorter period of day-night cycles than later-evolved organisms. Supporting data were available from work aimed at increasing the production of unicellular algae used in industry. In Tetraselmis spp., which belongs to an ancient group, cycle periods shorter than $24 \mathrm{~h}$ resulted in better synchronization (Alvarez \& Gallardo, 1989) and higher growth rate (López-Rodas et al., 1992) than cycles with a period of $24 \mathrm{~h}$. Optimal cell division synchrony in the more recently evolved Conjugatophyceae at a cycle period of $24 \mathrm{~h}$ was also found by Alvarez et al. (1988). In addition, the period of several rhythms in early-evolving unicellular organisms have been reported to be shorter than in mammalian cells (Edmunds, 1988).

The origin and evolution of circadian rhythmicity, which controls the cell cycle in some of the investigated groups, remain obscure. Pittendrigh $(1965,1966)$ suggested that the daily light-dark cycle was the historical selective agent of circadian oscillation; hence, these circadian periodicities reflected an adaptation of the primitive cells to protect themselves against deleterious effects of solar irradiation. If a primitive oscillator had evolved when the solar day was short, it would have had a relatively short free-running period. Klevecz (1984) and Klevecz et al. (1984) suggested that modern circadian rhythms have evolved by organismic fusion and the coupling of systems with short-period oscillators that probably emerged when the Earth's rotation was rapid. Bünning (1986) proposed that the use of a circadian oscillator for measuring day length had developed 
independently in several phyla. If circadian oscillators appeared independently in several phyla that originated in different ages, it seems possible that those that appeared first had shorter cycles than those that originated later, due to the influence of the slowing down of the Earth's rotation. The question of whether prokaryotes lack or have circadian rhythms has caused debate (Edmunds, 1988), but recent work has indicated the presence of circadian rhythms in cyanobacteria prokaryotes (Grobelaar et al., 1986; Mitsui et al., 1986, 1987).

Why were these properties conserved for such a long time, when there seems to be no use for them? Species of Chroococcus and Nostoc have been living in 24 -h cycles for quite a while now. Why have strains not been selected in the more recent past that are perfectly adjusted to 24 -h cycles? A more fundamental objection relates to the possibility that a presently living species may be relatively young, although the group to which it belongs may be ancient. Furthermore, certain taxa such as the Prasinophyceae may be polyphyletic and may have developed at different moments in time. Nevertheless, we tentatively suggest that the coupling of cell division cycle to ancient day length may have become fixed as a quiescent character. Kollar \& Fisher (1980) showed that there are quiescent genes that, like those for tooth induction in chickens, can not be expressed under normal conditions, but can be expressed under abnormal conditions.

Other objections, which can be raised against the present hypothesis, concern the more recently evolved groups of diatoms, comprising several species that cannot be synchronized at all and other species with generation times as short as $6 \mathrm{~h}$ (Nelson \& Brand, 1979). Another example is the chlorophytan Hydrodictyon reticulatum, in which entrainment of metabolic rates to cycle lengths as short as $6: 6 \mathrm{~h}$ LD is possible (Pirson, 1957). It should be stated that some unicellular algae that divide asynchronously at high growth rates, at doubling times longer than the period of the light-dark cycle, tend to synchronize cell division at low growth rates, when doubling time exceeds the period of the light-dark cycle (Edmunds, 1988). This probably reflects the cellular ability to connect or disconnect photosynthesis to biosynthesis of energy storage products or to synthesis of cell cycle essentials such as DNA and proteins, with a complex connection between cell division and diurnal photosynthesis. In the present investigation, the species used were selected because: (1) several aspects of their cell division cycle have been previously analysed in detail (Costas \& López-Rodas, 1991c; Costas et al., 1992); and (2) they have doubling times around $24 \mathrm{~h}$, under standard laboratory conditions. Previous papers also suggested that the clones used here can, with respect to cell division synchrony, be considered as representative of the whole species (Aguilera, 1991; Costas \& LópezRodas, 1991a,c).

Although many problems make it difficult to prove the influence of the decreased rate of rotation of the Earth on cell division synchrony of unicellular algae, it remains a provocative hypothesis. Pannella (1972) and Mohr (1975) determined the number of solar days per lunar month from depositional periodicities in stromatolites, and suggested that cellular oscillators are vestiges of a primitive circadian clock. Further studies on seaweeds that exhibit circannual and circadian growth rhythms are needed to help clarifiy our hypothesis (cf. Lüning, 1991, 1993, 1994).

Acknowledgements. Thanks are due to several anonymous referees for their suggestions that helped improve the manuscript. This work was supported by DGICYT PS89-0014 and PB91-0369. 


\section{LITERATURE CITED}

Aguilera, A., 1991, Influencia de la tasa de desaceleración terrestre sobre la duración del ciclo celular en microalgas. Dis., Univ. Autonoma Madrid, $40 \mathrm{pp}$.

Alvarez, M., Velasco, J., Rubio, A. \& Brook, A., 1988. Phased cell division by a field population of Staurastrum longiradiatum (Conjugatophyceae, Desmidiaceae). - Arch. Hydrobiol. 112, 1-20.

Alvarez, M. \& Gallardo, T., 1989. Una revisión sobre la biotecnología de las algas. - Bot. Complutensis $15,9-60$.

Balzer, I. \& Hardeland, R., 1988. Influence of temperature on biological rhythms. - Int. J. Biometeorol. 32, 231-241.

Baroin, A., Perasso, R., Qu, L. H., Brugerolle, G., Bachellerie, J. P. \& Adoutte, A., 1988. Partial phylogeny of unicellular eukaryotes based on rapid sequencing of a portion of $28 \mathrm{~S}$ ribosomal RNA. - Proc. natn. Acad. Sci. U.S.A. 85, 3474-3478.

Brand, L. E.; 1982. Persistent diel rhythms in the chlorophyll fluorescence of marine phytoplankton species. - Mar. Biol. 69, 253-262.

Bott, M. H. P., 1982. The interior of the Earth: its structure, constitution and evolution. Arnold, London, $403 \mathrm{pp}$.

Bünning, E., 1973. The physiological clock. Springer, Berlin, $258 \mathrm{pp}$.

Bünning, E., 1986. Evolution der circadianen Rhythmik und ihrer Nutzung zur Tageslängenmessung. - Naturwissenschaften 73, 70-77.

Chisholm, S. W. \& Brand, L. E., 1981. Persistence of cell division phasing in marine phytoplankton in continuous light after entrainment to light-dark cycles. - J. exp. mar. Biol. Ecol. 41, $107-118$.

Costas, E. \& López-Rodas, V., 1990. Persistencia de la sincronía de la división celular en Prorocentrum triestinum Schiller (Dinophyceae). - Scientia mar. 54, 263-267.

Costas, E. \& López-Rodas, V., 1991a. Persistence of cell division synchrony in Spirogyra insignis (Gamophyceae): membrane proteoglycans transmitting synchronizing information through generations. - Chronobiol. int. 8, 85-92.

Costas, E. \& López-Rodas, V., 1991b. Evidence for an annual rhythm in cell ageing in Spirogyra insignis (Chlorophyceae). - Phycologia 30, 597-599.

Costas, E. \& López-Rodas, V., 1991c. On growth factors, cell division cycle and the eukaryotic origin. - Endocytobiosis Cell Res. 8, 89-92.

Costas, E., González-Gil, S., Aguilera, A. \& López-Rodas, V., 1992. A morphometrical analysis of ultrastructural changes during the cell cycle of Prorocentrum triestinum using stereology. Botanica mar. 35, 429-436.

Dodge, J. D., 1983. Dinoflagellates: investigation and phylogenetic speculation. - Br. phycol. J. 18, $335-356$.

Edmunds, L. N., 1965. Studies on synchronously dividing cultures of Euglena gracilis Klebs (strain Z). I. Attainment and characterization of rhythmic cell division. - J. cell. comp. Physiol. 66, 147-158.

Edmunds, L. N., 1984. Physiology of circadian rhythms in microorganisms. In: Advances in microbiol physiology. Ed. by A. H. Rose \& D. W. Tempest. Acad. Press, New York, 432 pp.

Edmunds, L. N., 1988. Cellular and molecular basis of biological clocks. Springer, New York, $497 \mathrm{pp}$.

Edmunds, L. N. \& Funch, R. R. 1969. Circadian rhythm of cell division in Euglena: effects of a random illumination regimen. - Science, N.Y. 165, 500-503.

Edmunds, L. N., Jay, M. E., Kohlmann, A., Liu, S. C., Merriam. V. H. \& Sternberg, H., 1976. The coupling effects of some thiol and other sulfur-containing compounds of the circadian rhythms of cell division in photosynthetic mutants of Euglena. - Arch. Microbiol. 108, 1-8.

Edmunds, L. N., Tay, D. E. \& Laval-Martin, D. L., 1982. Cell division cycles and circadian clocks. - Pl. Physiol., Lancaster 70, 297-302.

Foster, R. J., 1991. Historical geology. MacMillan, New York, 374 pp.

Grobelaar, N., Huang, T. C., Lin, H. Y \& Chow, T. J., 1986. Dinitrogenfixing endogenous rhythm in Synechococcus RF-1. - FEMS microbiol. Lett. 37, 173-178.

Guillard, R., 1975. Culture of phytoplankton for feeding marine invertebrates. In: Culture of marine invertebrate animals. Ed. by W. Smith \& M. Chanley. Plenum, New York, 26-60.

Gunderson, J. H., Elwood, H., Ingold, A., Kindle, K. \& Sogin, M., 1987. Phylogenetic relationships between chlorophytes, crysophytes and oomycetes. - Proc. natn. Acad. Sci. U.S.A. 84, $5823-5827$. 
Herzog, M., Boletzky, S. \& Soyer, M. O., 1984. Ultrastructural and biochemical nuclear aspects of eukaryote classification: independent evolution of the dinoflagellates as a sister group of the actual eukaryotes? - Origins Life 13, 205-215.

Hoek, C. van den, Jahn, H. M. \& Mann, D. G., 1993. Algen. Thieme, Stuttgart, 411 pp.

Homma, K. \& Hastings, W., 1989a. The S phase is discrete and is controlled by the circadian clock in the marine dinoflagellate Gonyaulax polyedra. - Exp. Cell Res. 182, 635-644.

Homma, K. \& Hastings, W., 1989b. Cell growth kinetics, division asymmetry and volume control at division in the marine dinoflagellate Gonyaulax polyedra: a model of circadian clock control of the cell cycle. - J. Cell Sci. 92, 303-318.

Homma, K., Haas, E. \& Hastings, W., 1990. Phase of the circadian clock is accurately transferred from mother to daughter cells in the dinoflagellate Gonyaulax polyedra. - Cell Biophys. 16, 85-97.

Klevecz, R. R., 1984. Cellular oscillators as vestiges of a primitive circadian clock. In: Cell cycle clocks. Ed. by L. N. Edmunds. Dekker, New York, 47-61.

Klevecz, R. R., Kauffman, S. A. \& Shymko, R. M., 1984. Cellular clocks and oscillators. - Int. Rev. Cytol. $86,97-128$.

Knoll, A. H., 1992. The early evolution of eukaryotes: a geological perspective. - Science, N.Y. 256, $622-627$

Kollar, E. J. \& Fisher, C., 1980. Tooth induction in chicken epithelium: expression of quiescent genes for enamel synthesis. - Science, N.Y. 207, 993-995.

Lee, R. E., 1989. Phycology. Cambridge Univ. Press, Cambridge, 645 pp.

Lenaers, G., Maroteaux, L., Michot, B. \& Herzog, M., 1989. Dinoflagellates in evolution. A molecular phylogenetic analysis of large subunit ribosomal RNA. - J. mol. Evol. 29, 40-51.

López-Rodas, V., Gonzalez de Chavarri, E., González-Gil, S. \& Costas, E., 1992. 24 -hours-less lightdark cycles and growth factors increasing the growth rate of Tetraselmis sp. - Korean J. Phycol. 7, $167-171$.

Lüning, K., 1991. Circannual growth rhythm in a brown alga, Pterygophyra californica. - Bot. Acta 104, 157-162.

Lüning, K., 1993. Environmental and internal control of seasonal growth in seaweeds. - Hydrobiologia $260 / 261,1-14$.

Lüning, K., 1994. Circadian growth rhythm in juvenile sporophytes of Laminariales (Phaeophyta). J. Phycol. 30, 190-199.

Margulis, L. \& Schwartz, K. V., 1982. Five kingdoms. An illustrated guide to the Phyla of life on Earth. Freeman, New York, $208 \mathrm{pp}$.

Mitsui, A., Kumazawa, S., Takahashi, A., Ikemoto, H., Cao, S. \& Ari, T., 1986. Strategy by which nitrogen-fixing unicellular cyanobacteria grow photoautotrophically. - Nature, Lond. 323, $720-722$.

Mitsui, A., Cao, S., Takahashi, A. \& Ari, T., 1987. Growth synchrony and cellular parameters of unicellular nitrogen-fixing marine cyanobacterium Synechococcus spp. strain Miami BG 043511 under continuous illumination. - Physiol. plant. 69, 1-8.

Mohr, R. E., 1975. Growth rhythm and the history of the Earth rotation. Wiley, London, $265 \mathrm{pp}$.

Muller, P. M. \& Stephenson, F. R., 1975. The accelerations of the Earth and Moon from early astronomical observations. In: Growth rhythms and the history of the Earth's rotation. Ed. by G. D. Rosenberg \& S. K. Runcorn. Wiley, London, 352-375.

Nelson, D. M. \& Brand, L. E., 1979. Cell division periodicity in 13 species of marine phytoplankton on a light-dark cycle. - J. Phycol. 15, 67-75.

Ostgaard, K. \& Jensen, A., 1982. Diurnal and circadian rhythms in the turbidity of growing Skeletonema costatum cultures. - Mar. Biol. 66, 261-268.

Panella, G., 1972. Paleontological evidence on the Earth's rotation history since early Precambrian. Astrophys. Space Sci. 16, 212-237.

Pirson, A., 1957. Induced periodicity of photosynthesis and respiration in Hydrodyction. In: Research in photosynthesis. Ed. by H. Gaffron. Interscience, New York, 440-449.

Pittendrigh, C. S., 1965. On the mechanism of the entrainment of a circadian clock by light cycles. In: Circadian clocks. Ed. by J. Aschoff. North-Holland, Amsterdam, 227-297.

Pittendrigh, C. S., 1966. Biological clocks. In: Science and the sixties. Ed. by D. L. Arm. Univ. of New Mexico, Albuquerque, 96-111.

Sokal, R. R. \& Rohlf, F. J., 1981. Biometry. Freeman, San Francisco, 859 pp. 
Sweeney, B. M., 1987. Rhythmic phenomena in plants. Acad. Press, San Diego, 172 pp.

Sweeney, B. M. \& Hastings, J. W., 1958. Rhythmic cell division in populations of Gonyaulax polyedra. - J. Protozool. 5, 217-224.

Wells, J. W., 1963. Coral growth and geochronometry. - Nature, Lond. 197, 948-950.

Williams, M., 1977. Stereological techniques. In: Practical methods in electron microscopy. Ed. by A. M. Glanert. Elsevier, Amsterdam, 1, 216 pp. 